favourably in some respects with that induced by natural infection further attempts should be aimed at developing vaccines which when administered parenterally result in immunity, including perhaps cell-mediated immune responses, which closely resembles that acquired from natural infection.

Though considerable effort must continue in long-term surveillance on those given existing vaccines we feel that insufficient attention is being directed towards the development and characterization of virus strains which may have biological properties which may render them more suitable for vaccines than those currently licensed. If it were possible to develop better immunogenic vaccines, and should these also be non-teratogenic, then one would be aproaching the ideal vaccine. Unfortunately the lack of a suitable animal model has hindered progress in assessing the teratogenic capacity of rubella virus strains.

However, a Japanese report claimed that whereas the proportion of susceptible adults to rubella in Japan differed little from that in western countries congenitally acquired rubella infection was rare. Furthermore, studies employing rabbits suggested that lowpassage, U.S.-derived strains were teratogenic whereas Japanese ones were not, ${ }^{7}$ but unfortunately other workers have had difficulty in confirming these findings. However, it has recently been shown that when compared with low-passage U.S. and U.K. isolates and vaccine strains Japanese strains induce high interferon levels in human placental cell cultures. ${ }^{8}$ Though this might suggest that such strains might provide satisfactory vaccine strains further attempts to confirm the Japanese findings, together with more precise epidemiological data on the incidence of congenitally acquized infection in Japan, are urgently required.

Nevertheless, considerable progress has already been achieved, for within a decade of the first isolation of rubella virus satisfactory attenuated vaccines are now available. However, in many ways the journey to eradicate congenitally acquired rubella is only beginning and further research into the selection of suitable candidate vaccine strains and the immune responses they induce is required.-We are, etc.,

J. E. Banatvala JENNIFER M. BEST

Department of Virology,
St. Thomas's Hospital,

London S.E.1

1 Davis, W. J., Larson, H. E., Simsarian, J., P., the American Medical Association, 1971, 215. 600 .

2 Wilkins, J., Leedom, J. M., Portnoy, B., and Salvatore, M. A., American Fournal of Diseases of Children, 1969, 118, 275.

American fournal of Diseases of Children, 1969 , American.

4 Meyer, H. M. jr., Parkman, P. D., Hobbins, T. E., and Ennis, F. A., American fournal of Diseases of Children, 1968, 115, 648.

5 Ogra, P. L.., Kerr-Grant, D., Umana, G., Dzierba J., and Weintraub. D., New England fournal of Medicine, 1971, 285, 1333 .

Le Bouvier, G. L., and Plotkin, S. A., fourmal of Infectious Diseases, 1971, 123, 220.

Kono, R., Hibi, M., Hayakawa, Y., and Ishii, K.,

Banatvala, J. E., Potter, J. E., and Best, J. M.,
fournal of General Virology, 1971, 13, 193.

\section{Treatment of Early Breast Cancer}

SIR,-When simpler methods of treating breast cancer are being considered by $\mathrm{Sir}$
Hedley Atkins and his colleagues (20 May, p. 423) it is surely extraordinary they do not mention the pioneer work of Sir Geoffrey Keynes. ${ }^{14-16}$ Even more surprising is their failure to say that Keynes clearly stated in the 1920s the indications for local excision and irradiation and also its limitations. And why did Atkins and his colleagues limit their trial to women aged over 50? Your leading article (20 May, p. 417), in ascribing radical mastectomy to $W$. S. Halstead, ${ }^{1}$ fails to give credit to Charles Moore, of the Middlesex Hospital, who first described truly radical mastectomy. ${ }^{2}$

I regard the Guy's experiment as disappointing for a number of reasons. Whether or not one agrees with Mr. E. S. Lee, and others (17 June, p. 711) that this trial has "compared radical surgery plus suboptimal radiotherapy with partial surgery plus suboptimal radiotherapy," I believe that the Guy's group could have rendered a greater service to patients and surgeons had they, for example, compared radical surgery with extended simple mastectomy without radiotherapy to either group. As one who never accepted the advocacy of the "thiotepa umbrella," I regret that they included adjuvant chemotherapy during the first seven years, though I sympathize with their original reasons for this measure.

I would have suggested comparison of radical and simple surgery alone for further reasons. Firstly, because this would have been simpler for both doctors and patients, while certainly as ethical as the current Cambridge/King's trial referred to by Dr. Diana M. Brinkley and others (10 June, p. 652). Secondly, and with the greatest respect to $\mathrm{Mr}$. Lee and others, I agree with Dr. Brinkley and her colleagues that previous trials $3-5$ suggest that to add routine postoperative radiotherapy to radical surgery may be both unnecessary and positively harmful. Thirdly, I would have favoured this purely surgical essay as complementary to the Cambridge/King's trial, which is trying to compare the merits of simple mastectomy alone with simple mastectomy plus radiotherapy.

A retrospective study of 1,042 cases at St. Bartholomew's Hospital ${ }^{6}$ convinced me that different methods of treatment, though possibly important in a few cases, made little or no difference to survival. But it was plain that the simpler methods pioneered by Keynes contributed significantly to the quality of life. Since then most British surgeons have moved towards a more conservative practice. ${ }^{7}$ Like other surgeons, I have for many years selectively done wide local excision. ${ }^{9}$ But I would be unhappy to conduct a controlled trial to compare strictly alternate cases of wide local excision with either simple or radical mastectomy, notwithstanding supplementary irradiation.

Sir Hedley and his colleagues are right in stating that comparisons between series are dangerous, but they then go on to make a comparison with Kaae and Johansen's trial. ${ }^{1011}$ I once stressed ${ }^{12}$ a number of well-recognized statistical hazards which continued to trap the very elite in assessing the results in the treatment of breast cancer. Perhaps the least known of these is the possible inverse correlation between staged survival rate and the strictness of staging. Thus, if two observers separately stage a single series the observer with the stricter standards can come out with a better percentage survival in all stages despite the fact there is the same number of total survivors. If Sir Hedley seeks to compare his figures with Kaae and Johansen's he must give us total survival figures as well as the detailed survival rate for each stage. Even then it would be bold to attempt to draw valid comparisons.

Despite our earlier advocacy of simple mastectomy plus postoperative radiotherapy ${ }^{6}$ I have, rightly or wrongly, become more reluctant to expose my patients to routine postoperative irradiation. For more than 12 years I have preferred extended simple mastectomy (including accessible nodes, excluding pectoral muscles, and whenever possible through a transverse incision). This has proved infinitely simpler and less taxing for patients and the few local recurrences have been dealt with by surgery or irradiation or both.

Clearly there are many permutations of this disease, which require a varied approach. But in cases of early breast carcinoma (assuming that the word "early" can be judged to have any real validity in this context) let us strive to make treatment as simple as possible. And may I echo Keynes, who believed that "any rule-of-thumb in surgery is wholly pernicious."13 Finally, let Sir Hedley and his colleagues rest assured that those of us who have carefully studied their paper, and who recognize the immense labour which has gone into it, are duly impressed with the facts. Alas, and with the greatest of respect to him and his team, I feel bound to say that the design and execution of their research seems either to have obscured or left unanswered as many problems as before.-I am, etc.,

Reginald S. MURLeY

Radlett,

1 Halstead, W. S., Annals of Surgery, 1894, $20,497$. , $1867,3,133$.

Paterson, R., and Russell, M. H., fournal of the Faculty of Radiologists, 1959, 10.'175.

fournal of Surgery, 1969,

Fisher, B., in Surgery Annual, ed. P. Cooper, and L. M. Nyhus, 3rd edn., p. 227. New York, Williams, I. G. Murley, R. S. and Curwen, M. P., Briti h Medical fournal, 1953, 2, 787. Forrest, A. $P$. M., British Foumal of Surgery,

Crile, G., jun. A Biological Concideration of
Treatment of Breast Cancer. Springfield, Charles C. Thomas, 1967 .

9 Crile, G., jun., Lancet, 1972, 1, 549.

10 Kaae, S. and Johansen, H., in Prognostic Factors in Breast Cancer, ed. A. P. M. Forrest and
P. B. Kunkler, p. 93. Edinburgh, Livingstone, 1968. Kaae, S., and J J

12 Murley, 170. 895. Canadian Medical Association Mournal, 1956, 74, 427 Fournal, 1956, 74, 427.
Keynes, G. L., Proceedings of the Cardiff Medical
Society, 195i, p. 40.

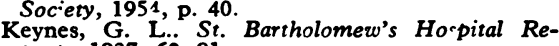
ports, $1927,60.91$. ports, 1927, 60. 91. Radiologica (Stockholm), 1929,
10. 393. G. Acta Radis.

Kevnes, G. L., British fournal of Surgery, 1932,

SIR,-YYour leading article on the treatment of early carcinoma of the breast (20 May, p. 417) stated that carcinoma of the breast "was the first neoplasm to be subiected to adequate, wide surgical excision at the end of the last century, when radical mastectomy was introduced by Halsted." I am sure there must be a number of other claimants, but I would bring your attention to the fact that the first laryngectomy for carcinoma of the 